\title{
A COMPARATIVE STUDY OF INTEGRATED FMCDM METHODS FOR EVALUATION OF ORGANIZATIONAL STRATEGY DEVELOPMENT
}

\author{
Nimet YAPICI PEHLIVAN ${ }^{1^{*}(\mathbb{D})}$, Aynur ŞAHİN ${ }^{(\mathbb{D})}$, \\ Edmundas Kazimieras ZAVADSKAS ${ }^{3}{ }^{(\mathbb{D})}$, Zenonas TURSKIS ${ }^{4}$ \\ 1, 2 Statistics Department, Science Faculty, University of Selçuk, Konya, Turkey \\ ${ }^{3}$ Construction Technology and Management Department, Civil Engineering Faculty, \\ Vilnius Gediminas Technical University, Vilnius, Lithuania \\ ${ }^{4}$ Research Institute of Smart Building Technologies, \\ Vilnius Gediminas Technical University, Vilnius, Lithuania
}

Received 15 June 2017; accepted 27 June 2018

\begin{abstract}
With the globalization of economy and development of technology, organizational strategy development in distribution channel management has become more significant for competitive business world. To improve distribution channel performance, many companies have focused on Multi-Criteria Decision Making (MCDM) methods. In the literature, there are a great number of studies on MCDM and fuzzy MCDM (FMCDM) methods, whereas a few studies on integrated FMCDM methods. The purpose of this study is to propose integrated FMCDM methodology including FAHP, WASPAS-F, EDAS-F and ARAS-F. In these methods, relative importances of the criteria are determined by FAHP. Managerial and financial perspective is determined as the most important criteria by FAHP methods. Then WASPAS-F, EDAS-F and ARAS-F methods are carried out to rank the alternatives. The practical implication of the integrated FMCDM methods is the use of linguistic variables for assessment of the criteria and the alternatives. As a research implication, Hybrid Based Strategy is determined as the best organizational strategy. The originality and value of study is to present comparative analyzes using the newly developed WASPAS-F, EDAS-F and ARAS-F integrated with FAHP methods. An important finding of the study is that the ranking results of the proposed methods are consistent with each other.
\end{abstract}

Keywords: multi-criteria decision making, FAHP, WASPAS-F, EDAS-F, ARAS-F, organizational strategy, distribution channel management.

JEL Classification: C00, D81, L29.

*Corresponding author. E-mail: nimet@selcuk.edu.tr 


\section{Introduction}

A distribution channel, also referred as a trade channel or a marketing channel, is defined as a set of independent organizations which included in the product making process or service process for use or consumption. A distribution channel is aimed to build the gap between producers and consumers by adding value to products or services. Manufacturers, intercessors such as wholesaler, retailer, specialized and end-users play an important role in the distribution channel (Coughlan, Anderson, Stern, \& El-Ansary, 2006). A distribution channel design needs two fundamental decisions: a strategic decision and a tactical decision. The number of levels between supplier and consumer is identified by the strategic decision, while the intensity of the selected structure and policies of channel management is determined by the tactical decision (Rangan \& Jaikumar, 1991). Distribution channel management has gained popularity and importance in the changing business world. There are several reasons for this: $i$ ) distribution and its network have become a significant origin of achievement and competitive advantage, $i$ i) distribution channel strategies influence many other aspects of marketing strategies, iii) Choosing distribution network has long-term outcomes, and it is very difficult to change the structure because of its cost (Guan, 2010). Development of a suitable organizational strategy is the most difficult stage of distribution channel management and it directly affect the success of management and distribution (Paksoy, Yapıcı Pehlivan, \& Kahraman, 2012).

Because of the globalization and fast-changing technologies in the competitiveness business world, production industries have to choose suitable production strategies, product designs, production processes, work piece and tool materials, machinery and equipment, etc. Decision makers (DMs) in the production industries frequently have faced with the problem of evaluating a set of alternatives and choosing one based on a set of conflicting criteria. Multiple criteria decision making (MCDM) methods help to determine suitable alternatives which makes a significant change in the productivity and profitability of the manufacturing industries (Rao, 2013). In order to deal with a typical MCDM method, firstly the number of criteria existing in the problem is determined. Secondly, the suitable data/information in which the preferences of DMs is collected (i.e., construction of the preferences). Thirdly, a set of possible alternatives for attaining the goal is constructed (i.e., evaluation of the alternatives). Finally, a proper method is chosen for evaluating and ranking of the alternatives (i.e., determination of the top alternative) (Tzeng \& Huang, 2011).

Fuzzy multi-criteria decision making (FMCDM) methods have been employed increasingly for the evaluation of the alternatives considering multiple, usually conflicting criteria under fuzzy environment. In the literature, FMCDM methods have been comprehensively studied by various researchers and applied to different fields. According to the Clarivate Analytics Web of Science database, a numerous published papers (article, article in press, review, book chapter, and book) on FMCDM methods in "article title, abstract, or keywords". Among these, a large number of published papers have been mentioned in their abstracts, keywords and titles as shown in Figure 1.

In this study, integrated fuzzy MCDM methods, FAHP/WASPAS-F, FAHP/EDAS-F, and FAHP/ARAS-F, are performed to improve an organizational strategy in distribution channel 


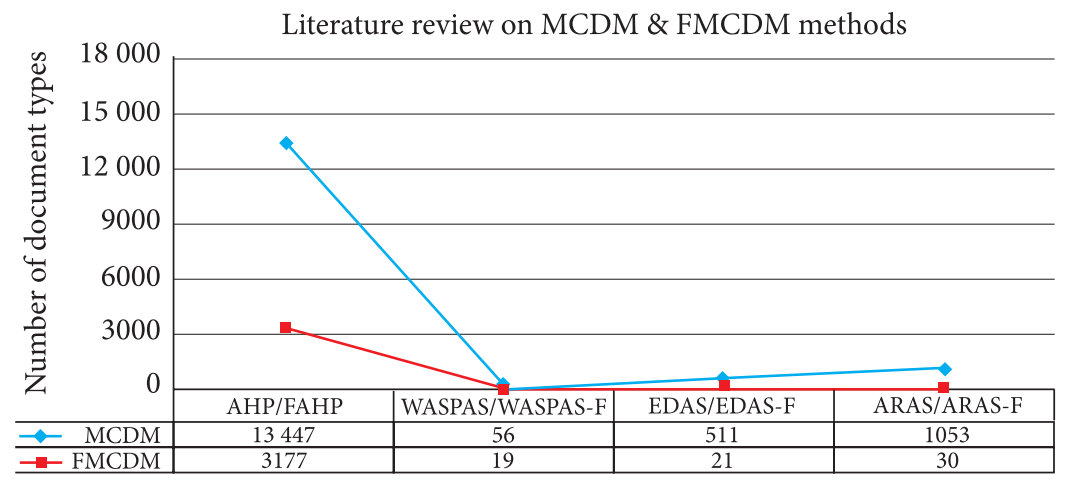

Figure 1. Published documentary using MCDM \& FMCDM methods over years considering their abstracts, keywords and titles

management of an edible-vegetable oil firm. As far as we know, there are no comparative studies on integrated FMCDM methods for determining the best organizational strategy under fuzzy environment by this time. The rest of this paper is organized as follows. In Section 1, a literature review on FMCDM methods are presented. The methods of FAHP, WASPAS-F, EDAS-F, and ARAS-F are summarized in Section 2. In Section 3, hierarchical structure of organizational strategy development problem and solution results of the integrated FMCDM methods are given. Finally, conclusions are drawn.

\section{Literature review}

A number of literature reviews or art of the state surveys on MCDM methods have been presented by various authors. Some of them reviewed the applications and methodologies of the MCDM techniques and approaches (Mardani et al., 2015; Sabaei, Erkoyuncu, \& Roy, 2015), while the others focused on MCDM techniques applied in specific areas, such as water management (Hajkowicz \& Collins, 2007), sustainable energy planning (Cavallaro, 2015), supplier evaluation and selection (Ho, Xu, \& Dey, 2010), bioenergy schemes (Scott, Hu, \& Dey, 2012), construction (Jato-Espino, Castillo-Lopez, Rodriguez-Hernandez, \& CanterasJordana, 2014), municipal solid waste management (Soltani, Hewage, Reza, \& Sadiq, 2015), green supplier evaluation and selection (Govindan, Rajendran, Sarkis, \& Murugesan, 2015), reverse logistics (Rezaei, 2015) Besides, some authors reviewed the MCDM methods under fuzzy environment (Çelik, Gül, Aydın, \& Güneri, 2015; Kahraman, Onar, \& Öztayşi, 2015).

Various MCDM and FMCDM methods are applied to solve different type of real world problems. Saaty (1980) proposed the Analytic Hierarchy Process (AHP) for planning, priority setting, resources allocation. Kahraman, Engin, Kabak and Kaya (2009) proposed an interactive group decision-making methodology, through the FTOPSIS to choose/rank Information Systems providers for a manufacturer. Turskis, Lazauskas and Zavadskas (2012) presented fuzzy multiple criteria assessment of construction site alternatives for non-hazardous waste incineration plant in Vilnius city, using the AHP and ARAS-F methods. A. Baležentis, T. Baležentis and Misiunas (2012) applied three FMCDM methods, FVIKOR, FTOPSIS, and 
ARAS-F, for assessment of Lithuanian economic sectors on the basis of financial ratios. Turskis, Zavadskas, Antucheviciene and Kosareva (2015) proposed the structure of fuzzy multiattribute performance measurement using the WASPAS-F and FAHP. Ghorabaee, Zavadskas, Amiri and Turskis (2016) introduced EDAS-F method which is an extension of EDAS method under fuzzy environment, for supplier selection of detergent manufacturer which needs to supply chemical materials. Kahraman et al. (2017) proposed intuitionistic fuzzy EDAS method for evaluation of solid waste disposal site selection.

A tabulated summary of the integrated FMCDM applications on various fields is presented in Table 1.

Table 1. Some of the literature summary on integrated FMCDM methods for various application area

\begin{tabular}{|c|c|c|}
\hline Authors & $\begin{array}{l}\text { Fuzzy MCDM } \\
\text { methods used }\end{array}$ & Application area \\
\hline $\begin{array}{l}\text { Kaya and Kahraman } \\
(2010)\end{array}$ & FAHP/FVIKOR & $\begin{array}{l}\text { Selection of the renewable energy alternative for Istan- } \\
\text { bul, Turkey }\end{array}$ \\
\hline $\begin{array}{l}\text { Önüt, Efendigil and } \\
\text { Kara (2010) }\end{array}$ & FAHP/FTOPSIS & $\begin{array}{l}\text { Evaluation of a shopping center site selection problem } \\
\text { in Istanbul, Turkey }\end{array}$ \\
\hline Sun $(2010)$ & FAHP/FTOPSIS & $\begin{array}{l}\text { Performance evaluation for providing a more accurate, } \\
\text { effective, and systematic decision support tool }\end{array}$ \\
\hline $\begin{array}{l}\text { Kaya and Kahraman } \\
\text { (2011) }\end{array}$ & FAHP/VIKOR & Selection of the alternative forestation areas in Istanbul \\
\hline $\begin{array}{l}\text { Büyüközkan, Arse- } \\
\text { nyan and Ruan (2012) }\end{array}$ & FAHP/FTOPSIS & $\begin{array}{l}\text { Evaluation of personal digital assistants with integrated } \\
\text { barcode scanner in the Turkish market }\end{array}$ \\
\hline $\begin{array}{l}\text { Kannan, Khodaverdi, } \\
\text { Olfat, Jafarian and } \\
\text { Diabat (2013) }\end{array}$ & FAHP/FTOPSIS & $\begin{array}{l}\text { Determination of the best green suppliers in an auto- } \\
\text { mobile manufacturing company }\end{array}$ \\
\hline $\begin{array}{l}\text { Senthil, Srirangacha- } \\
\text { ryulu and Ramesh } \\
\text { (2014) }\end{array}$ & FAHP/FTOPSIS & $\begin{array}{l}\text { Selection of contractor in third-party reverse logistics } \\
\text { for a plastic recycling plant in India }\end{array}$ \\
\hline $\begin{array}{l}\text { Taylan, Bafail, Abdu- } \\
\text { laal and Kabli (2014) }\end{array}$ & FAHP/FTOPSIS & $\begin{array}{l}\text { Evaluation of the construction projects and assessment } \\
\text { of their overall risk }\end{array}$ \\
\hline $\begin{array}{l}\text { Akkaya, Turanoğlu } \\
\text { and Öztaş (2015) }\end{array}$ & FAHP/FMOORA & $\begin{array}{l}\text { Evaluation of industrial engineering students and } \\
\text { graduates }\end{array}$ \\
\hline $\begin{array}{l}\text { Prakash and Barua } \\
(2015)\end{array}$ & FAHP/FTOPSIS & $\begin{array}{l}\text { Identification and ranking the solutions of Reverse } \\
\text { Logistics adoption in Indian electronics industry }\end{array}$ \\
\hline Turskis et al. (2015) & FAHP/WASPAS-F & $\begin{array}{l}\text { Selection of shopping centre construction site in } \\
\text { Vilnius }\end{array}$ \\
\hline $\begin{array}{l}\text { Dinçer, Hacioğlu, } \\
\text { Tatoğlu and Delen } \\
(2016)\end{array}$ & FAHP/FTOPSIS & $\begin{array}{l}\text { Determination of the industry alternatives for portfolio } \\
\text { investments in BIST } 100 \text { Index in Turkey }\end{array}$ \\
\hline $\begin{array}{l}\text { Liao, Fu and } \mathrm{Wu} \\
\text { (2016) }\end{array}$ & FAHP/ARAS-F & $\begin{array}{l}\text { Evaluation and selection of green supplier for a watch } \\
\text { manufacturer company }\end{array}$ \\
\hline $\begin{array}{l}\text { Nguyen, Dawal, } \\
\text { Nukman, Rifai and } \\
\text { Aoyama (2016) }\end{array}$ & FAHP/ARAS-F & $\begin{array}{l}\text { Selection of the conveyor system for improving the } \\
\text { performance of flexible manufacturing cells }\end{array}$ \\
\hline
\end{tabular}


End of Table 1

\begin{tabular}{|l|l|l|}
\hline \multicolumn{1}{|c|}{ Authors } & \multicolumn{1}{|c|}{$\begin{array}{c}\text { Fuzzy MCDM } \\
\text { methods used }\end{array}$} & \multicolumn{1}{c|}{ Application area } \\
\hline $\begin{array}{l}\text { Chauhan and Singh } \\
\text { (2016) }\end{array}$ & FAHP/FTOPSIS & $\begin{array}{l}\text { Determination of a sustainable location of healthcare } \\
\text { waste disposal facility for an Indian city }\end{array}$ \\
\hline $\begin{array}{l}\text { Rostamzadeh, Es- } \\
\text { maeili, Nia, Saparus- } \\
\text { kas and Ghorabee } \\
(2017)\end{array}$ & ARAS-F & $\begin{array}{l}\text { Performance measurement for supply chain manage- } \\
\text { ment in SMEs under uncertainty }\end{array}$ \\
\hline $\begin{array}{l}\text { Turskis, Kersuliene } \\
\text { and Vinogradova } \\
\text { (2017) }\end{array}$ & ARAS-F/AHP & $\begin{array}{l}\text { Decision-making approach to solve personnel assess- } \\
\text { ment problems }\end{array}$ \\
\hline Liao et al. (2016) & ARAS-F/FAHP & Evaluation and selection of green supplier \\
\hline $\begin{array}{l}\text { Mardani et al. (2017) } \\
\text { WASPAS-F/FAHP }\end{array}$ & $\begin{array}{l}\text { A systematic review and meta-Analysis of SWARA and } \\
\text { WASPAS methods }\end{array}$ \\
\hline $\begin{array}{l}\text { Ghorabaee, Amiri, } \\
\text { Olfat and Khatami } \\
\text { Firouzbadi (2017) }\end{array}$ & EDAS-F & $\begin{array}{l}\text { Designing a multi-product multi-period supply chain } \\
\text { network with reverse logistics and multiple objectives } \\
\text { under uncertainty }\end{array}$ \\
\hline
\end{tabular}

\section{Fuzzy multi-criteria decision making methods}

Multiple criteria decision making (MCDM) is the most well-known branch of decision making. MCDM problem is to select an appropriate alternative among a finite number of feasible alternatives in the presence of multiple, generally conflicting criteria. MCDM problems are classified into two categories: multi-objective decision making (MODM) and multi-attribute decision making (MADM), depends on the domain of the alternatives, i.e. continuous or discrete. MADM concentrates on problems with discrete domain whose number of alternatives has been predetermined in order to select/prioritize/rank a finite number of alternatives. On the other hand, MODM focuses on problems with decision variables that are determined in a continuous/integer domain with either an infinitive or a large number of alternatives to satisfy the decision maker's constraints and preference priorities (Rao, 2013). Various methods have been proposed in the field of MCDM, such as AHP (Saaty, 1980), TOPSIS (Hwang \& Yoon, 1981), COPRAS (Zavadskas, Kaklauskas, \& Sarka, 1994), VIKOR (Opricovic, 2007), MOORA (Brauers \& Zavadskas, 2006), MultiMOORA (Brauers \& Zavadskas, 2010), ARAS (Zavadskas and Turskis, 2010), WASPAS (Zavadskas, Turskis, Antucheviciene, \& Zakarevicius, 2012), EDAS (Ghorabaee, Zavadskas, Olfat, \& Turskis, 2015), etc. Due to the judgments and preferences of decision makers are influenced by uncertainty, the use of definite and crisp numbers in linguistic evaluations is not appropriate for MCDM methods. Therefore, various MCDM methods based on fuzzy set theory have been proposed by several authors for selection, ordering and classification of the alternatives. For example, Fuzzy AHP was first proposed by Van Laarhoven and Pedrycz (1983) as an extension of AHP method under fuzzy environment. The Fuzzy TOPSIS was first developed by Chen (2000) to extend TOPSIS method to the fuzzy environment. Opricovic and Tzeng (2002) introduced Fuzzy VIKOR to use fuzzy inputs for VIKOR method and then, Opricovic (2007) proposed a fuzzy 
extension of VIKOR to find a fuzzy compromise solution using triangular fuzzy numbers. Recently, Turskis and Zavadskas (2010) proposed ARAS-F method, Brauers, A. Baležentis and T. Baležentis (2011) introduced fuzzy MULTIMOORA method, Turskis et al. (2015) introduced WASPAS-F method and Ghorabaee et al. (2016) proposed EDAS-F method by using fuzzy set theory.

\subsection{Fuzzy Analytical Hierarchy Process (FAHP)}

Fuzzy Analytical Hierarchy Process (FAHP) is a fuzzy extension of AHP developed by Saaty (1980) in order to solve MCDM problems under fuzzy environment. There are five main methods of FAHP which are proposed by Van Laarhoven and Pedrycz (1983), Buckley (1985), Chang (1996), and Mikhailov (2002, 2003). In the methods, fuzzy pairwise comparison matrices have been constructed by using linguistic evaluations with respect to the decision makers' judgments. Van Laarhoven and Pedrycz (1983) proposed Fuzzy Priority Method method which is based on the logarithmic regression method, to derive fuzzy weights or fuzzy performance scores through AHP operations by using triangular fuzzy numbers (Van Laarhoven \& Pedrycz, 1983). The geometric mean method was first developed by Buckley (1985) to extend the AHP using linguistic variables. The extent analysis method proposed by Chang (1996) has been widely used to obtain crisp weights from a fuzzy comparison matrix. The Fuzzy Preference Programming (FPP) method was proposed by Mikhailov (2000) to derive weights from fuzzy comparison judgments. In the FPP method, initial fuzzy judgments are transformed into interval ones by using $\alpha$-cuts and it is applied to derive crisp weights from the interval judgments by solving any optimization problem (Mikhailov, 2002, 2003). The fuzzy prioritization (FP) method introduced by Mikhailov (2003) is based on the maximin decision rule which is applied for solving fuzzy linear problems with constraints.

In this study, geometric mean method of Buckley (1985) and fuzzy prioritization method of Mikhailov (2003) are performed to obtain weights of the criteria.

\subsubsection{Buckley (1985)'s Geometric Mean Method}

The Geometric Mean Method of FAHP (BGM-FAHP) proposed by Buckley (1985), is an extension of the AHP for the fuzzy case and it has been used to derive fuzzy weights. The advantages of this method are its computational simplicity and ensuring a unique solution. BGM-FAHP method is summarized as follows:

Step 1: The fuzzy pairwise comparison matrices $\tilde{D}=\left[\tilde{a}_{\hat{i} j}\right]_{n \times n}$ are constructed. Where $\tilde{a}_{i j}=\left(a_{i j}^{L}, a_{i j}^{M}, a_{i j}^{U}\right), i, j=1, \ldots, n$ indicates fuzzy comparison value of criterion $i$ to criterion $j$.

Step 2: The fuzzy geometric mean of criterion $i$ is calculated by Eq. (1):

$$
\tilde{r}_{i}=\left(\tilde{a}_{i 1} \otimes \tilde{a}_{i 2} \otimes \ldots \otimes \tilde{a}_{i n}\right)^{1 / n} .
$$

Step 3: The fuzzy weights of criterion $i$ is computed as in Eq. (2):

$$
\tilde{w}_{i}=\tilde{r}_{i} \otimes\left(\tilde{r}_{1} \oplus \tilde{r}_{2} \oplus \ldots \oplus \tilde{r}_{n}\right)^{-1},
$$

where $\oplus$ is fuzzy addition operator; $\otimes$ is fuzzy multiplication operator.

Step 4: The fuzzy weights $\tilde{w}_{i}$ are defuzzified by using Center of Area (CoA) method as follows: 


$$
w_{i}=w_{i}^{L}+\left(\frac{\left(w_{i}^{U}-w_{i}^{L}\right)+\left(w_{i}^{M}-w_{i}^{L}\right)}{3}\right)=\frac{w_{i}^{L}+w_{i}^{M}+w_{i}^{U}}{3},
$$

where $\tilde{w}_{i}=\left(w_{i}^{L}, w_{i}^{M}, w_{i}^{U}\right)$ denotes a triangular fuzzy number.

\subsubsection{Mikhailov (2003)'s Fuzzy Prioritization Method}

The Fuzzy Prioritization Method of FAHP (MFP-FAHP) proposed by Mikhailov (2003) is based on the maximin decision rule it has been used to derive crisp weights. The maximin rule was applied by Bellman and Zadeh (1970) for solving decision making problems in uncertain environments and it is applied by Zimmermann (1978) for fuzzy linear problems with constraints. The steps of the MFP-FAHP are given as follows:

Step 1: The fuzzy pairwise comparison matrices $\tilde{D}=\left[\tilde{a}_{\hat{\imath} j}\right]$ are set.

Step 2: The maximin prioritization problem is considered as follows,

$\operatorname{Max} \lambda$

$$
\begin{aligned}
& \lambda \leq \mu_{i j}(w), j>i ; \\
& \sum_{k=1}^{n} w_{k}=1, w_{k}>0,
\end{aligned}
$$

where $\lambda$ is a variable for measuring the degree of membership of a given priority vector in the fuzzy feasible area; $w_{k}$ is weight of criterion $k ; \mu_{i j}(w)$ is membership function of $w$.

Step 3: The maximum prioritization problem which is transformed into a nonlinear optimization model taking into consideration of the membership functions for the TFNs, is obtained by Eq. (5):

$\operatorname{Max} \lambda$

$$
\begin{aligned}
& \left(a_{i j}^{M}-a_{i j}^{L}\right) \lambda w_{j}-w_{i}+a_{i j}^{L} w_{j} \leq 0, j>i ; \\
& \left(a_{i j}^{U}-a_{i j}^{M}\right) \lambda w_{j}+w_{i}-a_{i j}^{U} w_{j} \leq 0, j>i ; \\
& \sum_{k=1}^{n} w_{k}=1, w_{k}>0 ; \quad k=1,2, \ldots, n .
\end{aligned}
$$

Step 4: By using any nonlinear optimization method, optimal solution of $\left(\lambda^{*}, w^{*}\right)$ is obtained. If $\lambda^{*}$ is positive, fuzzy comparison matrix is rather consistent. If $\lambda^{*}$ is negative, the fuzzy comparison matrix is strongly inconsistent (Mikhailov, 2003; Mikhailov \& Tsvetinov, 2004).

\subsection{Fuzzy Weighted Aggregated Sum-Product Assessment method (WASPAS-F)}

Weighted Aggregated Sum-Product Assessment (WASPAS) method was introduced by Zavadskas et al. (2012) which is composed of two well-known methods: Weighted Sum Model (WSM) and Weighted Product Model (WPM). In the WSM method, ranking score of an each alternative is computed as a weighted sum of the performance score by criteria weights. On the other hand, it is calculated as a multiplication of the performance score by taking power of the criteria weight, in the WPM. Based on these methods, Turskis et al. (2015) introduced WASPAS-F method extending the WASPAS method to the fuzzy environment. 
In summary, the WASPAS-F method can be described in ten steps:

Step 1: Constitute a Decision makers (DMs) group and define the evaluation criteria, alternatives, and goal of problem.

Step 2: Assign the fuzzy performance scores $\left(\tilde{x}_{i j k}, i=1,2, \ldots, m ; j=1,2, \ldots, n ; k=1,2, \ldots, K\right)$ for alternatives with respect to each criteria by the $\mathrm{DM}_{k}$ using appropriate linguistic evaluations.

Step 3: Identify the criteria importance $\tilde{w}_{j k}$ by the $\mathrm{DM}_{k}$ using appropriate linguistic evaluations or alternatively obtained by any fuzzy MCDM methods, such as FAHP.

Step 4: Transform the linguistic evaluations into corresponding triangular fuzzy numbers.

Step 5: Aggregate the fuzzy performance scores and the criteria importance of the DMs using Eqs. (6)-(7), respectively

$$
\begin{aligned}
& \tilde{x}_{i j}=\frac{1}{K}\left[\tilde{x}_{i j 1} \oplus \tilde{x}_{i j 2} \oplus \ldots \oplus \tilde{x}_{i j k}\right] ; \\
& \tilde{w}_{j}=\frac{1}{K}\left[\tilde{w}_{j 1} \oplus \tilde{w}_{j 2} \oplus \ldots \oplus \tilde{w}_{j k}\right],
\end{aligned}
$$

where $\tilde{x}_{i j k}$ is the fuzzy performance score for alternative $i$ with respect to criterion $j$ by the $\mathrm{DM}_{\mathrm{k}}$ and $\tilde{w}_{j k}$ is the importance of criterion $j$ by the $\mathrm{DM}_{k}$.

Step 6: Constitute the fuzzy decision matrix $\tilde{D}=\left[\tilde{x}_{i j}\right], i=1,2, \ldots, m ; j=1,2, \ldots, n$ and criteria weights vector $\tilde{w}_{j}$.

Step 7: Construct the normalized fuzzy decision matrix $\tilde{R}=\left[\tilde{r}_{i j}\right]$ by using Eq. (8),

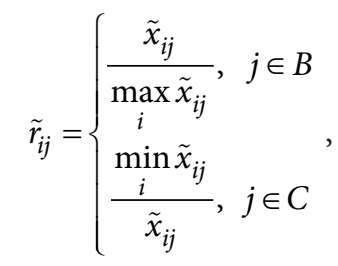

where $j \in B$ indicates benefit criteria and $j \in C$ indicates cost criteria.

Step 8: Compute the weighted normalized fuzzy decision matrices for WSM and WPM as in Eqs. (9)-(10), respectively.

$$
\begin{gathered}
\tilde{V}_{W S M}=\left[\tilde{v}_{i j, W S M}\right], \tilde{v}_{i j, W S M}=\tilde{r}_{i j} \otimes \tilde{w}_{j} ; \\
\tilde{V}_{W P M}=\left[v_{i j, W P M}\right], \tilde{v}_{i j, W P M}=\tilde{r}_{i j} \tilde{w}_{j} .
\end{gathered}
$$

Step 9: Compute fuzzy values of the optimality function for each alternative according to the WSM and WPM, respectively;

$$
\begin{aligned}
& \tilde{Q}_{i}=\sum_{j=1}^{n} \tilde{v}_{i j, W S M}, \quad i=1, \ldots, m ; \\
& \tilde{P}_{i}=\prod_{j=1}^{n} \tilde{v}_{i j, W P M}, \quad i=1, \ldots, m .
\end{aligned}
$$

The centre-of-area (CoA) method is used for defuzzification of fuzzy values as follows:

$$
Q_{i}=\frac{1}{3}\left(Q_{i}^{L}+Q_{i}^{M}+Q_{i}^{U}\right) ;
$$




$$
P_{i}=\frac{1}{3}\left(P_{i}^{L}+P_{i}^{M}+P_{i}^{U}\right) .
$$

Step 10: Calculate the integrated utility function value for each alternative by using Eqs. (15)-(16) and then rank the alternatives in decreasing order of $K_{i}$ :

$$
K_{i}=\lambda \sum_{i=1}^{m} Q_{i}+(1-\lambda) \sum_{i=1}^{m} P_{i}, \lambda=0, \ldots, 1 ; 0 \leq K_{i} \leq 1
$$

where

$$
\lambda=\frac{\sum_{i=1}^{m} P_{i}}{\sum_{i=1}^{m} P_{i}+\sum_{i=1}^{m} Q_{i}} .
$$

\subsection{Fuzzy evaluation based on distance from average solution (EDAS-F) method}

Evaluation based on distance from average solution (EDAS) method was developed by Ghorabaee et al. (2015) to handle MCDM problems. Later, Ghorabaee et al. (2016) proposed an extended version of the EDAS method to deal with multi-criteria group decision-making problems in the fuzzy environment. In the method, namely EDAS-F, the decision-makers express the weights of criteria and the rating of alternatives with respect to each criterion by linguistic terms which are quantified by positive trapezoidal fuzzy numbers. The algorithm of the EDAS-F method is presented as follows:

Step 1-6: Same as in the WASPAS-F algorithm.
Step 7: Determine the matrix of average solutions, $A V=\left[\tilde{a v_{j}}\right]_{1 \times n}$, as follows:

$$
\tilde{a v_{j}}=\frac{1}{m}\left[\sum_{i=1}^{m} \oplus \tilde{x}_{i j}\right]
$$

where $a \tilde{v}_{j}$ represents the average solutions with respect to each criterion.

Step 8: Calculate the positive distance from average matrix, $P D A=\left[p \tilde{d} a_{i j}\right]_{m \times n}$, and

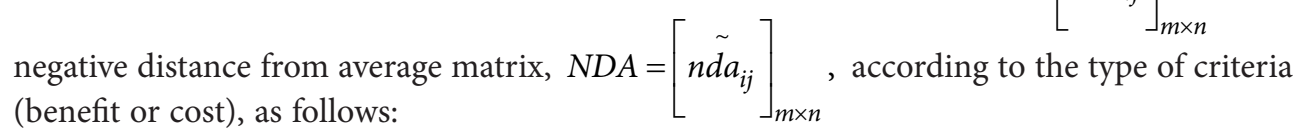

$$
\tilde{p d a_{i j}}=\left\{\begin{array}{c}
\frac{\psi\left(\tilde{x}_{i j} \Theta \tilde{a} v_{j}\right)}{\sim(\tilde{a v})}, j \in B \\
\frac{\psi\left(\tilde{a} v_{j} \Theta \tilde{x}_{i j}\right)}{\sim(\tilde{a v})}, j \in C,
\end{array}\right.
$$




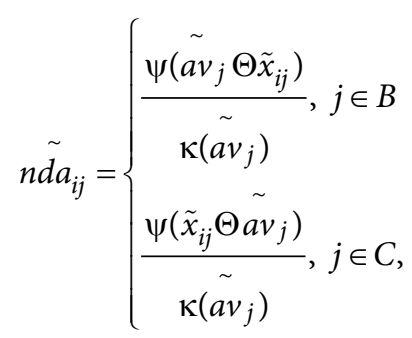

where $\psi$ is a function to find the maximum between a trapezoidal fuzzy number and zero; $\kappa$ is a function to find defuzzified (crisp) value of fuzzy number; $p d a_{i j}$ and $n d a_{i j}$ denote the positive and negative distance of performance value of alternative $i$ from the average solution in terms of criterion $i$, respectively.

Step 9: Calculate the weighted sum of positive and negative distances for all alternatives, as follows:

$$
\begin{aligned}
\tilde{s p_{i}} & =\sum_{j=1}^{n} \oplus\left(\tilde{w}_{j} \otimes p \tilde{d} a_{i j}\right) ; \\
\sim n_{i} & =\sum_{j=1}^{n} \oplus\left(\tilde{w}_{j} \otimes n \tilde{d} a_{i j}\right) .
\end{aligned}
$$

Step 10: Normalize the values of $\tilde{s p_{i}}$ and $\tilde{s n_{i}}$ for all alternatives as:

$$
\begin{gathered}
\tilde{P}_{i}=\frac{\tilde{s p_{i}}}{\max _{i}\left(\tilde{\kappa}\left(s p_{i}\right)\right)} ; \\
\tilde{R_{i}}=\frac{s n_{i}}{\max _{i}\left(\kappa\left(s n_{i}\right)\right)} .
\end{gathered}
$$

Step 11: Calculate the appraisal score $\left(U_{i}\right)$ using defuzzified $P_{i}$ and $R_{i}$ values for all alternatives, as follows:

$$
U_{i}=\frac{1}{2}\left(P_{i} \oplus R_{i}\right)
$$

Step 12: Rank the alternatives according to the decreasing values of $U_{i}$ (Ghorabaee et al., 2016).

\subsection{Fuzzy Additive Ratio Assesment (ARAS-F) method}

Additive Ratio Assesment (ARAS) method introduced by Zavadskas and Turkis (2010) is based on a utility function value determining the complex relative efficiency of a reasonable alternative which is directly proportional to the relative effect of values and weights of the main criteria. After then, Turskis and Zavadskas (2010) developed fuzzy version of ARAS method, namely ARAS-F, to solve different problems in transport, construction, economics, technology and sustainable development. 
Step 1-5: Same as in the WASPAS-F method.

Step 6: Construct the fuzzy decision matrix

$$
\tilde{D}=\left[\tilde{x}_{i j}\right], i=0,1, \ldots, m ; j=1,2, \ldots, n,
$$

where $\tilde{x}_{0 j}$ represents optimal fuzzy performance score of criterion $j$. If optimal value of criterion $j$ is unknown, then $\tilde{x}_{0 j}=\left\{\left(\max _{i} \tilde{x}_{i j}, j \in B\right),\left(\min _{i} \tilde{x}_{i j} j \in C\right)\right\}$.

Step 7: Construct the normalized fuzzy decision matrix $\tilde{R}=\left[\tilde{r}_{i j}\right]$ using Eq. (25):

$$
\tilde{r}_{i j}=\left\{\begin{array}{l}
\frac{\tilde{x}_{i j}}{\sum_{i=1}^{m} \tilde{x}_{i j}}, j \in B \\
\left(\frac{\tilde{x}_{i j}}{\sum_{i=1}^{m} \tilde{x}_{i j}}\right)^{-1}, j \in C
\end{array} .\right.
$$

Step 8: Calculate the fuzzy weighted normalized decision matrix $\tilde{V}=\left[\tilde{v}_{i j}\right]$,

$$
\tilde{v}_{i j}=\tilde{r}_{i j} \otimes \tilde{w}_{j} .
$$

Step 9: Compute the fuzzy optimality function by Eq. (27):

$$
\tilde{S}_{i}=\sum_{j=1}^{n} \tilde{v}_{i j}, \quad i=1,2, \ldots, m
$$

Step 10: Defuzzify $\tilde{S}_{i}$ by CoA method and rank the alternatives with respect to the $S_{i}$ in decreasing order. Step 11: Rank the alternatives in increasing order of $K_{i}=\frac{S_{i}}{S_{0}}$ which indicates utility
degree (Turskis \& Zavadskas, 2010).

\section{A numerical example}

The proposed integrated FMCDM methods are applied to determine the best organizational strategy in distribution channel management for an edible-vegetable oil manufacturer under fuzzy environment. Hierarchical structure of the problem have composed of three levels: the first level includes main criteria, the second level includes related sub-criteria and the third level includes alternatives as illustrated in Figure 2.

Detailed explanation of the main criteria, sub-criteria and the alternatives related to the problem can be found in (Paksoy et al., 2012). 


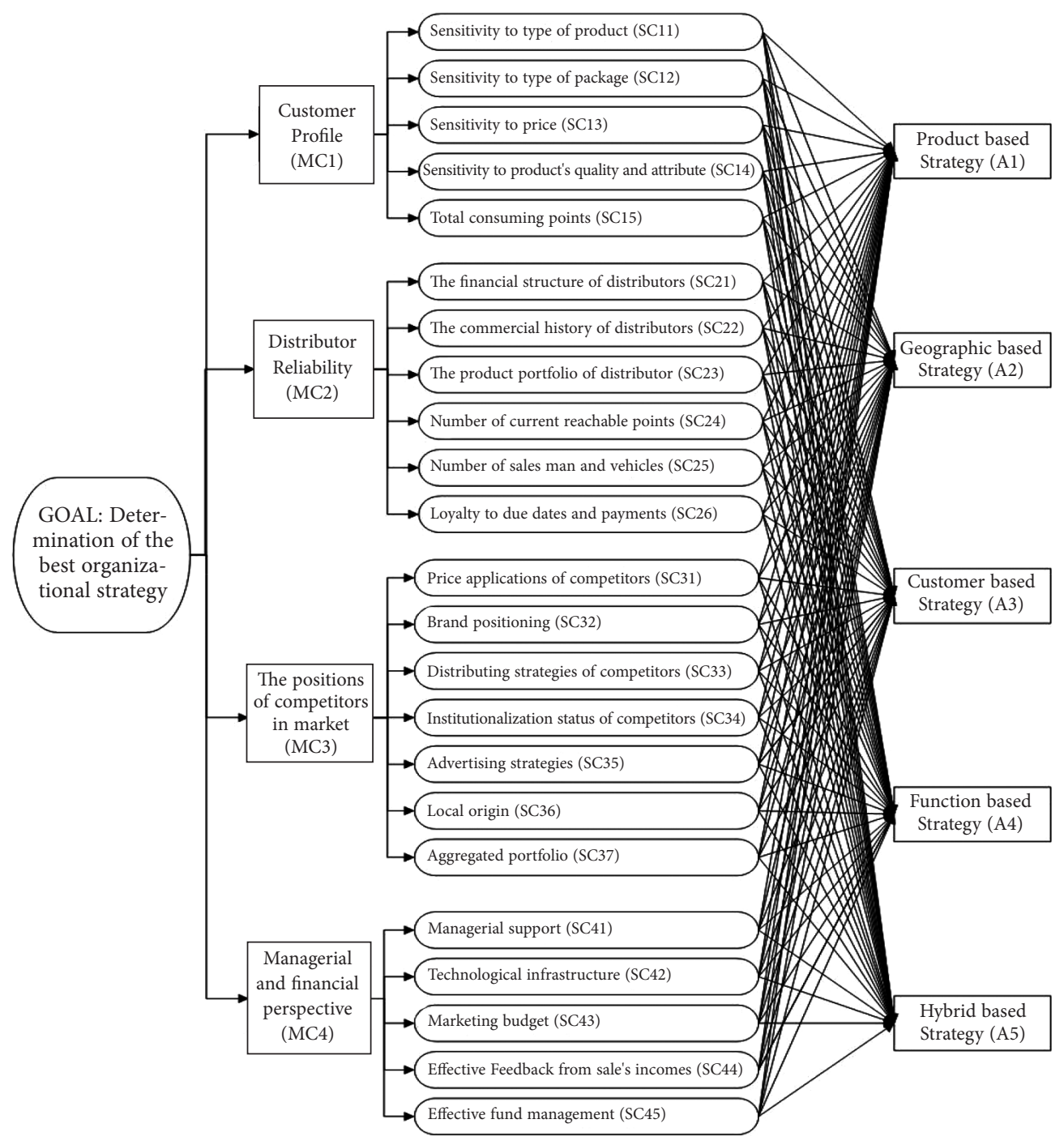

Figure 2. Hierarchical structure of the organizational strategy development

\subsection{Solution results the of FAHP Methods}

In this study, geometric mean method (BGM-FAHP) and Fuzzy Prioritization method (MFPFAHP) are performed to calculate the weights of the main criteria and related sub-criteria. Fuzzy pairwise comparison matrices which are constructed based on evaluations from the all Decision Makers by using linguistic terms and corresponding triangular fuzzy numbers given in Table 2, are given in Tables 3-7. The weights of all criteria for determining the best distribution channels computed by the methods of BGM-FAHP and MFP-FAHP are shown in Table 8. 
Table 2. Linguistic scale for FAHP

\begin{tabular}{|l|c|c|}
\hline Linguistic terms of importance & Triangular fuzzy numbers & $\begin{array}{c}\text { Reciprocal triangular } \\
\text { fuzzy numbers }\end{array}$ \\
\hline Equally important & $(1,1,1)$ & $(1,1,1)$ \\
\hline ...between equally and weakly & $(1,2,3)$ & $(1 / 3,1 / 2,1)$ \\
\hline Weakly important & $(2,3,4)$ & $(1 / 4,1 / 3,1 / 2)$ \\
\hline ..between weakly and strong & $(3,4,5)$ & $(1 / 6,1 / 5,1 / 4)$ \\
\hline Strong important & $(4,5,6)$ & $(1 / 7,1 / 6,1 / 5)$ \\
\hline $\begin{array}{l}\text {..between strong and very } \\
\text { strong }\end{array}$ & $(5,6,7)$ & $(1 / 8,1 / 7,1 / 6)$ \\
\hline Very strong & $(6,7,8)$ & $(1 / 9,1 / 8,1 / 7)$ \\
\hline $\begin{array}{l}\text {...between very strong and ab- } \\
\text { solutely strong }\end{array}$ & $(7,8,9)$ & $(1 / 9,1 / 9,1 / 9)$ \\
\hline Absolutely strong important & $(9,9,9)$ & \\
\hline
\end{tabular}

Table 3. Fuzzy comparison matrix for main criteria according to the goal

\begin{tabular}{|c|c|c|c|c|}
\hline Criteria & MC1 & MC2 & MC3 & MC4 \\
\hline MC1 & $(1,1,1)$ & $(4,5,6)$ & $(1,1,1)$ & $(1 / 4,1 / 3,1 / 2)$ \\
\hline MC2 & $(1 / 6,1 / 5,1 / 4)$ & $(1,1,1)$ & $(1 / 3,1 / 2,1)$ & $(1 / 6,1 / 5,1 / 4)$ \\
\hline MC3 & $(1,1,1)$ & $(1,2,3)$ & $(1,1,1)$ & $(1 / 3,1 / 2,1)$ \\
\hline MC4 & $(2,3,4)$ & $(4,5,6)$ & $(1,2,3)$ & $(1,1,1)$ \\
\hline
\end{tabular}

Table 4. Fuzzy comparison matrix for sub-criteria of MC1

\begin{tabular}{|c|c|c|c|c|c|}
\hline Sub-criteria & SC11 & SC12 & SC13 & SC14 & SC15 \\
\hline SC11 & $(1,1,1)$ & $(2,3,4)$ & $(1 / 4,1 / 3,1 / 2)$ & $(1 / 4,1 / 3,1 / 2)$ & $(1 / 3,1 / 2,1)$ \\
\hline SC12 & $(1 / 4,1 / 3,1 / 2)$ & $(1,1,1)$ & $(1 / 6,1 / 5,1 / 4)$ & $(1 / 4,1 / 3,1 / 2)$ & $(1,2,3)$ \\
\hline SC13 & $(2,3,4)$ & $(4,5,6)$ & $(1,1,1)$ & $(1 / 3,1 / 2,1)$ & $(1,2,3)$ \\
\hline SC14 & $(2,3,4)$ & $(2,3,4)$ & $(1,2,3)$ & $(1,1,1)$ & $(2,3,4)$ \\
\hline SC15 & $(1,2,3)$ & $(1 / 3,1 / 2,1)$ & $(1 / 3,1 / 2,1)$ & $(1 / 4,1 / 3,1 / 2)$ & $(1,1,1)$ \\
\hline
\end{tabular}

Table 5. Fuzzy comparison matrix for sub-criteria of MC2

\begin{tabular}{|c|c|c|c|c|c|c|}
\hline Sub-criteria & SC21 & SC22 & SC23 & SC24 & SC25 & SC26 \\
\hline SC21 & $(1,1,1)$ & $(1,1,1)$ & $(4,5,6)$ & $(2,3,4)$ & $(2,3,4)$ & $(1,2,3)$ \\
\hline SC22 & $(1,1,1)$ & $(1,1,1)$ & $(2,3,4)$ & $(2,3,4)$ & $(2,3,4)$ & $(1,2,3)$ \\
\hline SC23 & $(1 / 6,1 / 5,1 / 4)$ & $(1 / 4,1 / 3,1 / 2)$ & $(1,1,1)$ & $(1,1,1)$ & $(1,2,3)$ & $(1,2,3)$ \\
\hline SC24 & $(1 / 4,1 / 3,1 / 2)$ & $(1 / 4,1 / 3,1 / 2)$ & $(1,1,1)$ & $(1,1,1)$ & $(1,1,1)$ & $(1,2,3)$ \\
\hline SC25 & $(1 / 4,1 / 3,1 / 2)$ & $(1 / 4,1 / 3,1 / 2)$ & $(1 / 4,1 / 3,1 / 2)$ & $(1 / 3,1 / 2,1)$ & $(1,1,1)$ & $(1,2,3)$ \\
\hline SC26 & $(1 / 3,1 / 2,1)$ & $(1 / 3,1 / 2,1)$ & $(1 / 3,1 / 2,1)$ & $(1 / 3,1 / 2,1)$ & $(1 / 3,1 / 2,1)$ & $(1,1,1)$ \\
\hline
\end{tabular}


Table 6. Fuzzy comparison matrix for sub-criteria of MC3

\begin{tabular}{|c|c|c|c|c|c|c|c|}
\hline $\begin{array}{c}\text { Sub- } \\
\text { criteria }\end{array}$ & SC31 & SC32 & SC33 & SC34 & SC35 & SC36 & SC37 \\
\hline SC31 & $(1,1,1)$ & $(1 / 6,1 / 5,1 / 4)$ & $(1 / 3,1 / 2,1)$ & $(2,3,4)$ & $(1,2,3)$ & $(1,2,3)$ & $(1,1,1)$ \\
\hline SC32 & $(4,5,6)$ & $(1,1,1)$ & $(1 / 3,1 / 2,1)$ & $(2,3,4)$ & $(1,2,3)$ & $(1,1,1)$ & $(1,2,3)$ \\
\hline SC33 & $(1,2,3)$ & $(1,2,3)$ & $(1,1,1)$ & $(2,3,4)$ & $(1,1,1)$ & $(2,3,4)$ & $(2,3,4)$ \\
\hline SC34 & $(1 / 4,1 / 3,1 / 2)$ & $(1 / 4,1 / 3,1 / 2)$ & $(1 / 4,1 / 3,1 / 2)$ & $(1,1,1)$ & $(1 / 3,1 / 2,1)$ & $(1,2,3)$ & $(1 / 4,1 / 3,1 / 2)$ \\
\hline SC35 & $(1 / 3,1 / 2,1)$ & $(1 / 3,1 / 2,1)$ & $(1,1,1)$ & $(1,2,3)$ & $(1,1,1)$ & $(1,1,1)$ & $(1,1,1)$ \\
\hline SC36 & $(1 / 3,1 / 2,1)$ & $(1,1,1)$ & $(1 / 4,1 / 3,1 / 2)$ & $(1 / 3,1 / 2,1)$ & $(1,1,1)$ & $(1,1,1)$ & $(1 / 4,1 / 3,1 / 2)$ \\
\hline SC37 & $(1,1,1)$ & $(1 / 3,1 / 2,1)$ & $(1 / 4,1 / 3,1 / 2)$ & $(2,3,4)$ & $(1,1,1)$ & $(2,3,4)$ & $(1,1,1)$ \\
\hline
\end{tabular}

Table 7. Fuzzy comparison matrix for sub-criteria of MC4

\begin{tabular}{|c|c|c|c|c|c|}
\hline Sub-criteria & SC41 & SC42 & SC43 & SC44 & SC45 \\
\hline SC41 & $(1,1,1)$ & $(2,3,4)$ & $(1,1,1)$ & $(1,1,1)$ & $(1 / 4,1 / 3,1 / 2)$ \\
\hline SC42 & $(1 / 4,1 / 3,1 / 2)$ & $(1,1,1)$ & $(1,1,1)$ & $(1 / 4,1 / 3,1 / 2)$ & $(1 / 4,1 / 3,1 / 2)$ \\
\hline SC43 & $(1,1,1)$ & $(1,1,1)$ & $(1,1,1)$ & $(1,1,1)$ & $(1 / 3,1 / 2,1)$ \\
\hline SC44 & $(1,1,1)$ & $(2,3,4)$ & $(1,1,1)$ & $(1,1,1)$ & $(1 / 3,1 / 2,1)$ \\
\hline SC45 & $(2,3,4)$ & $(2,3,4)$ & $(1,2,3)$ & $(1,2,3)$ & $(1,1,1)$ \\
\hline
\end{tabular}

Table 8. The weights of the main criteria and its related sub-criteria

\begin{tabular}{|c|c|c|c|}
\hline Main criteria & Sub-criteria & BGM-FAHP & MFP-FAHP \\
\hline MC1 & & 0.2322 & 0.2307 \\
\hline \multirow{5}{*}{ MC2 } & SC11 & 0.1235 & 0.1538 \\
\cline { 2 - 4 } & SC12 & 0.0910 & 0.0769 \\
\cline { 2 - 4 } & SC13 & 0.2932 & 0.3076 \\
\cline { 2 - 4 } & SC14 & 0.3644 & 0.3076 \\
\hline \multirow{5}{*}{ SC15 } & 0.1279 & 0.1538 \\
\hline & & 0.0811 & 0.0770 \\
\cline { 2 - 4 } & SC21 & 0.3022 & 0.3333 \\
\cline { 2 - 4 } & SC22 & 0.2785 & 0.3333 \\
\cline { 2 - 4 } & SC23 & 0.1168 & 0.0833 \\
\cline { 2 - 4 } & SC24 & 0.1132 & 0.0833 \\
\hline \multirow{4}{*}{ MC3 } & SC25 & 0.0907 & 0.0833 \\
\hline \multirow{5}{*}{} & SC26 & 0.0985 & 0.0833 \\
\hline & & 0.2112 & 0.2307 \\
\cline { 2 - 4 } & SC31 & 0.1547 & 0.1250 \\
\cline { 2 - 4 } & SC32 & 0.2440 & 0.1250 \\
\cline { 2 - 4 } & SC33 & 0.2851 & 0.2500 \\
\hline
\end{tabular}


End of Table 8

\begin{tabular}{|c|c|c|c|}
\hline Main criteria & Sub-criteria & BGM-FAHP & MFP-FAHP \\
\hline \multirow{4}{*}{ MC4 } & SC35 & 0.1371 & 0.1250 \\
\cline { 2 - 4 } & SC36 & 0.0938 & 0.1250 \\
\cline { 2 - 4 } & SC37 & 0.1590 & 0.1250 \\
\hline \multirow{4}{*}{} & & 0.4755 & 0.4614 \\
\cline { 2 - 4 } & SC41 & 0.1786 & 0.1818 \\
\cline { 2 - 4 } & SC42 & 0.0964 & 0.0909 \\
\cline { 2 - 4 } & SC43 & 0.1575 & 0.1818 \\
\cline { 2 - 4 } & SC44 & 0.1979 & 0.1818 \\
\cline { 2 - 4 } & SC45 & 0.3696 & 0.3636 \\
\hline
\end{tabular}

In Table 8, the weights of the main criteria according to the goal are calculated as $(0.2322$, $0.0811,0.2112,0.4755)$ by using BGM-FAHP, whereas $(0.2307,0.0770,0.2307,0.4614)$ by using MFP-FAHP. The weights of the sub-criteria of MC1 are calculated as $(0.1627,0.1157$, $0.2629,0.3408,0.1790)$ by applying BGM-FAHP, whereas calculated as $(0.1538,0.0769$, $0.3076,0.3076,0.1538$ ) by using MFP-FAHP.

\subsection{Solution of the integrated Fuzzy MCDM methods}

Fuzzy decision matrices of the problem are constructed based on evaluations of the alternatives with respect to the all criteria from the DMs. Then, the weights of the all criteria and the performance score of the each alternative are aggregated. Final rankings of the alternatives are obtained by performing the steps of the algorithm of WASPAS-F, EDAS-F, and ARAS-F as shown in Tables 9-11.

Table 9. Results of the integrated FAHP/WASPAS-F method

\begin{tabular}{|c|c|c|c|c|c|c|c|c|}
\hline & \multicolumn{3}{|c|}{ BGM-FAHP /WASPAS-F } & \multicolumn{4}{c|}{ MFP-FAHP /WASPAS-F } \\
\hline $\begin{array}{c}\text { Alterna- } \\
\text { tives }\end{array}$ & WSM- $Q_{i}$ & WPM- $P_{\mathrm{i}}$ & $K_{i}$ & Ranking & WSM- $Q_{i}$ & WPM- $P_{i}$ & $K_{i}$ & Ranking \\
\hline A1 & 0.484 & 0.273 & 0.361 & 4 & 0.501 & 0.283 & 0.374 & 4 \\
\hline A2 & 0.520 & 0.377 & 0.437 & 2 & 0.526 & 0.380 & 0.441 & 2 \\
\hline A3 & 0.491 & 0.350 & 0.409 & 3 & 0.489 & 0.350 & 0.408 & 3 \\
\hline A4 & 0.282 & 0.171 & 0.217 & 5 & 0.287 & 0.177 & 0.223 & 5 \\
\hline A5 & 0.774 & 0.657 & 0.706 & 1 & 0.771 & 0.652 & 0.702 & 1 \\
\hline$\lambda$ & \multicolumn{6}{|c|}{0.417} & & \multicolumn{5}{c|}{0.417} & \\
\hline
\end{tabular}


Table 10. Results of the integrated FAHP/EDAS-F method

\begin{tabular}{|c|c|c|c|c|c|c|c|c|}
\hline & \multicolumn{4}{|c|}{ BGM-FAHP /EDAS-F } & \multicolumn{3}{c|}{ MFP-FAHP / EDAS-F } \\
\hline $\begin{array}{c}\text { Alterna- } \\
\text { tives }\end{array}$ & $P_{i}$ & $R_{i}$ & $U_{i}$ & Ranking & $P_{i}$ & $R_{i}$ & $U_{i}$ & Ranking \\
\hline A1 & -0.205 & 0.699 & 0.247 & 4 & -0.172 & 0.752 & 0.290 & 4 \\
\hline A2 & -0.060 & 0.912 & 0.426 & 3 & -0.061 & 0.912 & 0.426 & 2 \\
\hline A3 & -0.054 & 0.921 & 0.434 & 2 & -0.072 & 0.897 & 0.412 & 3 \\
\hline A4 & -0.681 & 0.000 & -0.341 & 5 & -0.695 & 0.000 & -0.347 & 5 \\
\hline A5 & 1.000 & 2.468 & 1.734 & 1 & 1.000 & 2.439 & 1.720 & 1 \\
\hline
\end{tabular}

Table 11. Results of the integrated FAHP/ARAS-F method

\begin{tabular}{|c|c|c|c|c|c|c|}
\hline & \multicolumn{3}{|c|}{ BGM-FAHP/ARAS-F } & \multicolumn{3}{c|}{ MFP-FAHP/ARAS-F } \\
\hline Alternatives & $S_{i}$ & $K_{i}$ & Ranking & $S_{i}$ & $K_{i}$ & Ranking \\
\hline A1 & 0.139 & 0.463 & 4 & 0.143 & 0.479 & 4 \\
\hline A2 & 0.155 & 0.515 & 2 & 0.155 & 0.519 & 2 \\
\hline A3 & 0.152 & 0.505 & 3 & 0.150 & 0.504 & 3 \\
\hline A4 & 0.089 & 0.295 & 5 & 0.090 & 0.301 & 5 \\
\hline A5 & 0.239 & 0.796 & 1 & 0.236 & 0.793 & 1 \\
\hline
\end{tabular}

According to the Tables 9-11, organizational strategy alternatives are ranked as A5 > A2 > A3 > A1 > A4 by using all integrated fuzzy MCDM methods except for BGM-FAHP/ EDAS-F. Hybrid based strategy (A5) is selected as the most preferred organizational strategy for the distribution channel management for the edible-vegetable oil manufacturer. These ranking results are similar to the ranking results of FAHP method of Chang (1996) and HFTOPSIS method of Ateş, Çevik, Kahraman, Gülbay and Erdoğan (2006), given in Paksoy et al. (2012) (Table 12). Spearman's rank correlation coefficients between the proposed methods and Chang's FAHP, HFTOPSIS presented by Paksoy et al. (2012) are calculated shown in Table 13. All the Spearman's rank correlation coefficients are statistically significant for $\alpha=$ 0.05 and it show that there is a significant relationship between the integrated fuzzy MCDM methods.

Table 12. Ranking results of proposed methods, FAHP and HFTOPSIS

\begin{tabular}{|c|c|c|c|c|c|c|c|c|}
\hline & \multicolumn{2}{|c|}{ BGM-FAHP/FMCDM } & \multicolumn{2}{c|}{ MFP-FAHP/FMCDM } & \multicolumn{2}{c|}{ Paksoy et al. (2012) } \\
\hline $\begin{array}{c}\text { Alterna- } \\
\text { tives }\end{array}$ & $\begin{array}{c}\text { WAS- } \\
\text { PAS-F }\end{array}$ & EDAS-F & ARAS-F & $\begin{array}{c}\text { WAS- } \\
\text { PAS-F }\end{array}$ & EDAS-F & ARAS-F & $\begin{array}{c}\text { Chang } \\
\text { FAHP }\end{array}$ & $\begin{array}{c}\text { HFTOP- } \\
\text { SIS }\end{array}$ \\
\hline A1 & 4 & 4 & 4 & 4 & 4 & 4 & 3 & 3 \\
\hline A2 & 2 & 3 & 2 & 2 & 2 & 2 & 2 & 2 \\
\hline A3 & 3 & 2 & 3 & 3 & 3 & 3 & 4 & 4 \\
\hline A4 & 5 & 5 & 5 & 5 & 5 & 5 & 5 & 5 \\
\hline A5 & 1 & 1 & 1 & 1 & 1 & 1 & 1 & 1 \\
\hline
\end{tabular}


Table 13. Correlations between ranking results of proposed integrated FMCDM methods, FAHP and HFTOPSIS

\begin{tabular}{|l|c|c|c|c|c|c|c|c|}
\hline \multicolumn{1}{|c|}{ Methods } & $\begin{array}{c}\text { BGM- } \\
\text { FAHP/ } \\
\text { WAS- } \\
\text { PAS-F }\end{array}$ & $\begin{array}{c}\text { BGM- } \\
\text { FAHP/ } \\
\text { EDAS-F }\end{array}$ & $\begin{array}{c}\text { BGM- } \\
\text { FAHP/ } \\
\text { ARAS-F }\end{array}$ & $\begin{array}{c}\text { MFP- } \\
\text { FAHP/ } \\
\text { WAS- } \\
\text { PAS-F }\end{array}$ & $\begin{array}{c}\text { MFP- } \\
\text { FAHP/ } \\
\text { EDAS-F }\end{array}$ & $\begin{array}{c}\text { MFP- } \\
\text { FAHP/ } \\
\text { ARAS-F }\end{array}$ & $\begin{array}{c}\text { Chang } \\
\text { FAHP }\end{array}$ & $\begin{array}{c}\text { HFTOP- } \\
\text { SIS }\end{array}$ \\
\hline $\begin{array}{l}\text { BGM- } \\
\text { FAHP/ } \\
\text { WASPAS-F }\end{array}$ & 1.000 & $0.900^{*}$ & $1.000^{* *}$ & $1.000^{* *}$ & $1.000^{* *}$ & $1.000^{* *}$ & $0.900^{*}$ & $0.900^{*}$ \\
\hline $\begin{array}{l}\text { BGM- } \\
\text { FAHP/ } \\
\text { EDAS-F }\end{array}$ & $0.900^{*}$ & 1.000 & $0.900^{*}$ & $0.900^{*}$ & $0.900^{*}$ & $0.900^{*}$ & 0.700 & 0.700 \\
\hline $\begin{array}{l}\text { BGM- } \\
\text { FAHP/ } \\
\text { ARAS-F }\end{array}$ & $1.000^{* *}$ & $0.900^{*}$ & 1.000 & $1.000^{* *}$ & $1.000^{* *}$ & $1.000^{* *}$ & $0.900^{*}$ & $0.900^{*}$ \\
\hline $\begin{array}{l}\text { MFP- } \\
\text { FAHP/ } \\
\text { WASPAS-F }\end{array}$ & $1.000^{* *}$ & $0.900^{*}$ & $1.000^{* *}$ & 1.000 & $1.000^{* *}$ & $1.000^{* *}$ & $0.900^{*}$ & $0.900^{*}$ \\
\hline $\begin{array}{l}\text { MFP-AHP/ } \\
\text { EDAS-F }\end{array}$ & $1.000^{* *}$ & $0.900^{*}$ & $1.000^{* *}$ & $1.000^{* *}$ & 1.000 & $1.000^{* *}$ & $0.900^{*}$ & $0.900^{*}$ \\
\hline $\begin{array}{l}\text { MFP- } \\
\text { FAHP/ } \\
\text { ARAS-F }\end{array}$ & $1.000^{* *}$ & $0.900^{*}$ & $1.000^{* *}$ & $1.000^{* *}$ & $1.000^{* *}$ & 1.000 & $0.900^{*}$ & $0.900^{*}$ \\
\hline $\begin{array}{l}\text { Chang } \\
\text { FAHP }\end{array}$ & $0.900^{*}$ & 0.700 & $0.900^{*}$ & $0.900^{*}$ & $0.900^{*}$ & $0.900^{*}$ & 1.000 & $1.000^{* *}$ \\
\hline \begin{tabular}{l} 
HFTOPSIS \\
\hline
\end{tabular} & $0.900^{*}$ & 0.700 & $0.900^{*}$ & $0.900^{*}$ & $0.900^{*}$ & $0.900^{*}$ & $1.000^{* *}$ & 1.000 \\
\hline
\end{tabular}

* Correlation is significant at the 0.05 level (2-tailed), ${ }^{*}$ Correlation is significant at the 0.01 level (2-tailed)

\section{Conclusions}

Distribution channel management has been played an important role in the competitive business world to provide a competitive advantage for companies in manufacturing industry. The managers in the manufacturing industry face with various decision making problems like as selecting or ranking the alternatives amongst a set of alternatives considering multiple, generally conflicting criteria. Determination of the distribution channel strategies which has long term outcomes, is one of the most difficult decision making processes.

In this study, we proposed integrated FMCDM methods for development of the organizational strategies in distribution channel management for an edible-vegetable oil company. Hierarchical structure of the problem consists of three levels: four main criteria, twentythree sub-criteria and five alternatives. At first, Buckley (1985)'s Geometric mean method and Mikhailov (2003)'s Fuzzy Prioritization method of FAHP are performed to calculate the weights of the main criteria and related sub-criteria. Then, WASPAS-F, EDAS-F, and ARAS-F methods are applied to rank organizational strategy alternatives

The results obtained from both BGM-FAHP and MFP-FAHP show that the managerial and financial perspective (MC4), composed of managerial support, technological infrastructure, 
marketing budget, effective feedback from sales' income and effective fund management, is the most important criteria among all criteria. The remaining criteria in order of priority are given as: customer profile (MC1), the positions of competitors in market (MC3) and distributor reliability (MC2). The other important findings from these results are that effective fund management (SC45) which can be used to determine the effect of imported materials on product price, has the biggest importance weight among the sub-criteria of the managerial and financial perspective (MC4). Hence, managers should improve managerial and financial perspective especially in terms of effective fund management to strengthen organizational strategies in distribution channel management for an edible-vegetable oil manufacturer.

According to the integrated FMCDM methods, ranking order of five organizational strategy alternatives ranked as A5 > A2 > A1 > A3 > A4 by all integrated FMCDM methods except for BGM-FAHP/EDAS-F. The results show that Hybrid Based Strategy (A5) is the best organizational strategy for an edible vegetable oil company. If the managers use this ranking in strategy selection, the greatest benefit for the company is provided. Moreover, the ranking results of the proposed methods are consistent with each other since all correlation coefficients are statistically significant. Thus, it can be said that proposed integrated FMCDM methods are practical for determination of the best organizational strategies in distribution channel management under fuzzy environment. The results of this study may help manufacturers to develop organizational strategies by identifying the most crucial criteria in distribution channel management.

The most important advantage of the proposed methods is that pair-wise comparisons of alternatives with respect to the each criterion are need not required in the evaluation process. Therefore, the computation time of the proposed integrated FMCDM methods is less than other MCDM methods under crisp/fuzzy environment.

As a limitation of this study, we only focused on developing organizational strategies for a particular edible-vegetable oil company in Turkey. When these integrated FMCDM methods applied to other companies operating in different sector, ranking results could be different. For future research, other MCDM methods such as DEMATEL, ELECTRE, COPRAS and DEA can be used for developing organizational strategy of distribution channel management under crisp or fuzzy environment.

\section{Acknowledgements}

We thank anonymous referees and Editor, who helped to improve the paper.

\section{Funding}

Authors do not have any funding.

\section{Author contributions}

Nimet YAPICI PEHLIVAN conceived the study and was responsible for the design and development of the data analysis. Nimet YAPICI PEHLIVAN, Aynur ŞAHIN, Edmundas ZAVADSKAS and Zeonas TURSKIS were responsible for data analysis and data interpretation. 


\section{Disclosure statement}

All authors declared that they have no any competing financial, professional or personal interests from other parties.

\section{References}

Akkaya, G., Turanoğlu, B., \& Öztaş, S. (2015). An integrated fuzzy AHP and fuzzy MOORA approach to the problem of industrial engineering sector choosing. Expert Systems with Applications, 42(24), 9565-9573. https://doi.org/10.1016/j.eswa.2015.07.061

Ateş, N. Y., Çevik, S., Kahraman, C., Gülbay, M., \& Erdoğan, S. A. (2006). Multi attribute performance evaluation using a hierarchical fuzzy TOPSIS method. In C. Kahraman (Ed.), Fuzzy applications in industrial engineering. Studies in fuzziness and computing (pp. 537-572). Berlin, Heidelberg: Springer. https://doi.org/10.1007/3-540-33517-x_22

Baležentis, A., Baležentis, T., \& Misiunas, A. (2012). An integrated assessment of Lithuanian economic sectors based on financial ratios and fuzzy MCDM methods. Technological and Economic Development of Economy, 18(1), 34-53. https://doi.org/10.3846/20294913.2012.656151

Bellman, R. E., \& Zadeh, L. A. (1970). Decision-making in a fuzzy environment. Management Science, 17(4), 141-164. https://doi.org/10.1287/mnsc.17.4.b141

Brauers, W., \& Zavadskas, E. (2006). The MOORA method and its application to privatization in a transition economy. Control and Cybernetics, 35, 445-469.

Brauers, W. K. M., Baležentis, A., \& Baležentis, T. (2011). MultiMOORA for the EU member states updated with fuzzy number theory. Technological and Economic Development of Economy, 17, 259290. https://doi.org/10.3846/20294913.2011.580566

Brauers, W. K. M., \& Zavadskas, E. K. (2010). Project management by MultiMOORA as an instrument for transition economies. Ukio Technologinis ir Ekonominis Vystymas, 16, 5-24.

https://doi.org/10.3846/tede.2010.01

Buckley, J. J. (1985). Fuzzy hierarchical analysis. Fuzzy Sets and Systems, 17(3), 233-247. https://doi.org/10.1016/0165-0114(85)90090-9

Büyüközkan, G., Arsenyan, J., \& Ruan, D. (2012). Logistics tool selection with two-phase fuzzy multi criteria decision making: a case study for personal digital assistant selection. Expert Systems with Applications, 39(1), 142-153. https://doi.org/10.1016/j.eswa.2011.06.017

Cavallaro, F. (2015). A Takagi-Sugeno fuzzy inference system for developing a sustainability index of biomass. Sustainability, 7(9), 12359-12371. https://doi.org/10.3390/su70912359

Çelik, E., Gül, M., Aydın, N., Gümüş, A. T., \& Güneri, A. F. (2015). A comprehensive review of multi criteria decision making approaches based on interval type-2 fuzzy sets. Knowledge-based Systems, 85, 329-341. https://doi.org/10.1016/j.knosys.2015.06.004

Chang, D. Y. (1996). Applications of the extent analysis method on fuzzy AHP. European Journal of Operational Research, 95(3), 649-655. https://doi.org/10.1016/0377-2217(95)00300-2

Chauhan, A., \& Singh, A. (2016). A hybrid multi-criteria decision making method approach for selecting a sustainable location of healthcare waste disposal facility. Journal of Cleaner Production, 139, 1001-1010. https://doi.org/10.1016/j.jclepro.2016.08.098

Chen, C. T. (2000). Extensions of the TOPSIS for group decision-making under fuzzy environment. Fuzzy Sets and Systems, 114, 1-9. https://doi.org/10.1016/S0165-0114(97)00377-1

Coughlan, A. T., Anderson, E., Stern, L. W., \& El-Ansary, A. I. (2006). Marketing channels (7 ${ }^{\text {th }}$ ed.). New Jersey: Pearson/Prentice Hall. 
Dinçer, H., Hacıŏlu, U., Tatoğlu, E., \& Delen, D. (2016). A fuzzy-hybrid analytic model to assess investors' perceptions for industry selection. Decision Support Systems, 86, 24-34.

https://doi.org/10.1016/j.dss.2016.03.005

Govindan, K., Rajendran, S., Sarkis, J., \& Murugesan, P. (2015). Multi criteria decision making approaches for green supplier evaluation and selection: a literature review. Journal of Cleaner Production, 98, 66-83. https://doi.org/10.1016/j.jclepro.2013.06.046

Guan, W. (2010). Developments in distribution channels - a case study of a timber product distribution channel (PhD thesis). Linköping Studies in Science and Technology, Linköping University, Sweeden.

Ghorabaee, M., Zavadskas, E. K., Olfat, L., \& Turskis, Z. (2015). Multi-criteria inventory classification using a new method of Evaluation based on Distance from Average Solution (EDAS). Informatica, 26(3), 435-451. https://doi.org/10.15388/informatica.2015.57

Ghorabaee, M., Zavadskas, E. K., Amiri, M., \& Turskis, Z. (2016). Extended EDAS method for fuzzy multi-criteria decision-making: an application to supplier selection. International Journal of Computers, Communications \& Control (IJCCC), 11(3), 358-371. https://doi.org/10.15837/ijccc.2016.3.2557

Ghorabaee, M., Amiri, M., Olfat, L., \& Khatami Firouzabadi, S. M. A. (2017). Designing a multiproduct multi-period supply chain network with reverse logistics and multiple objectives under uncertainty. Technological and Economic Development of Economy, 23(3), 520-548.

https://doi.org/10.1016/j.psep.2016.02.013

Hajkowicz, S., \& Collins, K. (2007). A review of multiple criteria analysis for water resource planning and management. Water Resources Management, 21(9), 1553-1566.

https://doi.org/10.1007/s11269-006-9112-5

Ho, W., Xu, X., \& Dey, P. K. (2010). Multi-criteria decision making approaches for supplier evaluation and selection: a literature review. European Journal of Operational Research, 202(1), 16-24.

https://doi.org/10.1016/j.ejor.2009.05.009

Hwang, C. L., \& Yoon, K. (1981). Multiple attribute decision making - methods and applications. New York: Springer. https://doi.org/10.1007/978-3-642-48318-9

Jato-Espino, D., Castillo-Lopez, E., Rodriguez-Hernandez, J., \& Canteras-Jordana, J. C. (2014). A review of application of multi-criteria decision making methods in construction. Automation in Construction, 45, 151-162. https://doi.org/10.1016/j.autcon.2014.05.013

Kahraman, C., Engin, O., Kabak, O., \& Kaya, İ. (2009). Information systems outsourcing decisions using a group decision-making approach. Engineering Applications of Artificial Intelligence, 22(6), 832-841. https://doi.org/10.1016/j.engappai.2008.10.009

Kahraman, C., Onar, S. Ç., \& Öztayşi, B. (2015). Fuzzy multicriteria decision-making: a literature review. International Journal of Computational Intelligence Systems, 8(4), 637-666. https://doi.org/10.1080/18756891.2015.1046325

Kahraman, C., Ghorabaee, M., Zavadskas, E. K., Çevik Onar, S., Yazdani, M., \& Öztayşi, B. (2017). Intuitionistic fuzzy EDAS method: an application to solid waste disposal site selection. Journal of Environmental Engineering and Landscape Management, 25(1), 1-12. https://doi.org/10.3846/16486897.2017.1281139

Kannan, D., Khodaverd, I. R., Olfat, L., Jafarian, A., \& Diabat, A. (2013). Integrated fuzzy multi criteria decision making method and multi-objective programming approach for supplier selection and order allocation in a green supply chain. Journal of Cleaner Production, 47, 355-367. https://doi.org/10.1016/j.jclepro.2013.02.010

Kaya, T., \& Kahraman, C. (2010). Multicriteria renewable energy planning using an integrated fuzzy VIKOR\& AHP methodology: the case of Istanbul. Energy, 35(6), 2517-2527. https://doi.org/10.1016/j.energy.2010.02.051 
Kaya, T., \& Kahraman, C. (2011). Fuzzy multiple criteria forestry decision making based on an integrated VIKOR and AHP approach. Expert Systems with Applications, 38(6), 7326-7333. https://doi.org/10.1016/j.eswa.2010.12.003

Liao, C. N., Fu, Y. K., \& Wu, L. C. (2016). Integrated FAHP, ARAS-F and MSGP methods for green supplier evaluation and selection. Technological and Economic Development of Economy, 22(5), 651669. https://doi:10.3846/20294913.2015.1072750

Mardani, A., Jusoh, A., Md Nor, K., Khalifah, Z., Zakwan, N., \& Valipour, A. (2015). Multiple criteria decision-making techniques and their applications - a review of the literature from 2000 to 2014. Economic Research-Ekonomska Istraživanja, 28(1), 516-571. https://doi.org/10.1080/1331677x.2015.1075139

Mardani, A., Nilashi, M., Zakuan, N., Loganathan, N., Soheilirad, S., Saman, M. Z. M., \& Ibrahim, O. (2017). A systematic review and meta-analysis of SWARA and WASPAS methods: theory and applications with recent fuzzy developments. Applied Soft Computing, 57, 265-292. https://doi.org/10.1016/j.asoc.2017.03.045

Mikhailov, L. (2002). Fuzzy analytical approach to partnership selection in formation of virtual enterprises. Omega, 30, 393-401. https://doi.org/10.1016/S0305-0483(02)00052-X

Mikhailov, L. (2003). Deriving priorities from fuzzy pairwise comparison judgements. Fuzzy Sets and Systems, 134(3), 365-385. https://doi.org/10.1016/s0165-0114(02)00383-4

Mikhailov, L., \& Tsvetinov, P. (2004). Evaluation of services using a fuzzy analytic hierarchy process. Applied Soft Computing, 5(1), 23-33. https://doi.org/10.1016/j.asoc.2004.04.001

Nguyen, H. T., Md Dawal, S. Z., Nukman, Y., Rifai, A. P., \& Aoyama, H. (2016). An integrated MCDM model for conveyor equipment evaluation and selection in an FMC based on a fuzzy AHP and fuzzy ARAS in the presence of vagueness. PLoS ONE, 11(4), e0153222. https://doi.org/10.1371/journal.pone.0153222

Opricovic, S., \& Tzeng, G. H. (2002). Multicriteria planning of post-earthquake sustainable reconstruction. Computer-Aided Civil and Infrastructure Engineering, 17, 211-220. https://doi.org/10.1111/1467-8667.00269

Opricovic, S. (2007). A fuzzy compromise solution for multicriteria problems. International Journal of Uncertainty, Fuzziness and Knowledge-Based Systems, 15(3), 363-380. https://doi.org/10.1142/S0218488507004728

Önüt, S., Efendigil, T., \& Kara, S. (2010). A combined fuzzy MCDM approach for selecting shopping center site: an example from Istanbul, Turkey. Expert Systems with Applications, 37(3), 1973-1980. https://doi.org/10.1016/j.eswa.2009.06.080

Paksoy, T., Pehlivan, N. Y., \& Kahraman, C. (2012). Organizational strategy development in distribution channel management using fuzzy AHP and hierarchical fuzzy TOPSIS. Expert Systems with Applications, 39(3), 2822-2841. https://doi.org/10.1016/j.eswa.2011.08.142

Prakash, C., \& Barua, M. K. (2015). Integration of AHP-TOPSIS method for prioritizing the solutions of reverse logistics adoption to overcome its barriers under fuzzy environment. Journal of Manufacturing Systems, 37, 599-615. https://doi.org/10.1016/j.jmsy.2015.03.001

Rangan, V. K., \& Jaikumar, R. (1991). Integrating distribution strategy and tactics: a model and an application. Management Science, 37(11), 1377-1389. https://doi.org/10.1287/mnsc.37.11.1377

Rao, R. V. (2013). Decision making in the manufacturing environment: using graph theory and fuzzy multiple attribute decision making methods. London: Springer-Verlag. https://doi.org/10.1007/978-1-4471-4375-8

Rezaei, J. (2015). A systematic review of multi-criteria decision-making applications in reverse logistics. Transportation Research Procedia, 10, 766-776. https://doi.org/10.1016/j.trpro.2015.09.030

Rostamzadeh, R., Esmaeili, A., Nia, A. S., Saparauskas, J., \& Ghorabaee, M. (2017). A fuzzy ARAS method for supply chain management performance measurement in smes under uncertainty. Transformations in Business \& Economics, 16(2A), 319-348. https://doi.org/10.3846/16111699.2017.1279683 
Saaty, T. L. (1980). The analytic hierarchy process: planning, priority setting, resource allocation. New York: McGraw-Hill.

Sabaei, D., Erkoyuncu, J., \& Roy, R. (2015). A review of multi-criteria decision making methods for enhanced maintenance delivery. Procedia CIRP, 37, 30-35. https://doi.org/10.1016/j.procir.2015.08.086

Scott, J. A., Ho, W., \& Dey, P. K. (2012). A review of multi-criteria decision-making methods for bioenergy systems. Energy, 42(1), 146-156. https://doi.org/10.1016/j.energy.2012.03.074

Senthil, S., Srirangacharyulu, B., \& Ramesh, A. (2014). A robust hybrid multi-criteria decision making methodology for contractor evaluation and selection in third-party reverse logistics. Expert Systems with Applications, 41(1), 50-58. https://doi.org/10.1016/j.eswa.2013.07.010

Soltani, A., Hewage, K., Reza, B., \& Sadiq, R. (2015). Multiple stakeholders in multi-criteria decisionmaking in the context of Municipal Solid Waste Management: a review. Waste Management, 35, 318-328. https://doi.org/10.1016/j.wasman.2014.09.010

Sun, C. C. (2010). A performance evaluation model by integrating fuzzy AHP and fuzzy TOPSIS methods. Expert Systems with Applications, 37(12), 7745-7754. https://doi.org/10.1016/j.eswa.2010.04.066

Taylan, O., Bafail, A. O., Abdulaal, R. M. S., \& Kabli, M. R. (2014). Construction projects selection and risk assessment by fuzzy AHP and fuzzy TOPSIS methodologies. Applied Soft Computing, 17, 105116. https://doi.org/10.1016/j.asoc.2014.01.003

Turskis, Z., \& Zavadskas, E. K. (2010). A new fuzzy additive ratio assessment method (ARAS-F). Case study: the analysis of fuzzy multiple criteria in order to select the logistic centers location. Transport, 25(4), 423-432. https://doi.org/10.3846/transport.2010.52

Turskis, Z., Lazauskas, M., \& Zavadskas, E. K. (2012). Fuzzy multiple criteria assessment of construction site alternatives for non-hazardous waste incineration plant in Vilnius city, applying ARAS-F and AHP methods. Journal of Environmental Engineering and Landscape Management, 20(2), 110-120. https://doi.org/10.3846/16486897.2011.645827

Turskis, Z., Zavadskas, E. K., Antucheviciene, J., \& Kosareva, N. (2015). A hybrid model based on fuzzy AHP and fuzzy WASPAS for construction site selection. International Journal Of Computers Communications \& Control, 10(6), 113-128. https://doi.org/10.15837/ijccc.2015.6.2078

Turskis, Z., Kersuliene, V., \& Vinogradova, I. (2017). A new fuzzy hybrid multi-criteria decision-making approach to solve personnel assessment problems. Case study: directo selection for estates and economy office. Economic Computation and Economic Cybernetics Studies and Research, 51(3), 211229. https://doi.org/10.3846/20294913.2011.635718

Tzeng, G. H., \& Huang, J. J. (2011). Multiple attribute decision making methods and applications. Boca Raton, FL: Chapman and Hall/CRC.

Van Laarhoven, P. J. M., \& Pedrycz, W. (1983). A fuzzy extension of Saaty's priority theory. Fuzzy Sets and Systems, 11(1-3), 229-241. https://doi.org/10.1016/S0165-0114(83)80082-7

Zavadskas, E. K., Kaklauskas, A., \& Sarka, V. (1994). The new method of multi-criteria complex proportional assessment of projects. Technological and Economic Development of Economy, 1(3), 131-139.

Zavadskas, E. K., \& Turskis, Z. (2010). A new additive ratio assessment (ARAS) method in multicriteria decision-making. Technological and Economic Development of Economy, 16(2), 159-172. https://doi.org/10.3846/tede.2010.10

Zavadskas, E. K., Turskis, Z., Antucheviciene, J., \& Zakarevicius, A. (2012). Optimization of weighted aggregated sum product assessment. Elektronika ir Elektrotechnika, 122(6), 1-6. http://dx.doi.org/10.5755/j01.eee.122.6.1810

Zimmermann, H. J. (1978). Fuzzy programming and linear programming with several objective functions. Fuzzy Sets and Systems, 1(1), 45-55. https://doi.org/10.1016/0165-0114(78)90031-3. 